J. Amer. Soc. Hort. ScI. 120(6):1069-1074. 1995.

\title{
Glucosinolates in Broccoli Stored under Controlled Atmosphere
}

\author{
Merete Hansen, ${ }^{1,2}$, Peter Møller ${ }^{3}$, and Hilmer Sørensen \\ The Royal Veterinary and Agricultural University, DK-1871 Frederiksberg C, Denmark \\ Marita Cantwell de Trejo ${ }^{4}$ \\ University of California, Davis, CA 95616
}

Additional index words. Brassica olerucea L. var. italica, methylsulphinylalkylglucosinolates, indol-3-ylmethylglucosinolates, desulphoglucosinolates, low-oxygen atmosphere

\begin{abstract}
Content of total and individual glucosinolates were determined in, 'Marathon' broccoli florets (Brassica olerucea L. var. italica stored 7 days at $10 \mathrm{C}$ under air, $0.5 \% \mathrm{O}_{2}, 0.5 \% \mathrm{O}_{2}+20 \% \mathrm{CO}_{2}$ or $20 \% \mathrm{CO}_{2}$ atmosphere, followed by transfer to air for 2 days. 'Marathon' broccoli contained glucoraphanin, glucobrassicin, neoglucobrassicin, glucoiberin, 4methoxyglucobrassicin, progoitrin, glucoalyssin, and gluconasturtiin. The methylssulfinylalkylglucosinolates (glucoiberin and glucoraphanin) and the indol-3-ylmethylglucosinolates (glucobrassicin, neoglucobrassicin and 4methoxyglucobrassicin) accounted for $78 \%$ and $20 \%$ of the total content, respectively, in freshly harvested broccoli. CA treatment and storage time had no significant effect on the relative content of these two groups of glucosinolates. Freshly harvested broccoli contained $47 \mu \mathrm{mol}$ glucosinolate/g dry weight. The total glucosinolate content increased $42 \%$ and $21 \%$ during 7 days storage under air and $0.5 \% \mathrm{O}_{2}+20 \% \mathrm{CO}_{2}$, respectively, as compared to freshly harvested broccoli, and decreased $15 \%$ in broccoli stored under $20 \% \mathrm{CO}_{2}$. Treatment with $20 \% \mathrm{CO}_{2}$ in the absence of 0 , resulted in visible $\mathrm{CO}$, injury and water soaking of the tissue. Aeration had no significant effect on total glucosinolate content but reduced the glucobrassicin content $35 \%$ in broccoli stored 7 days under $0.5 \% \mathrm{O}_{2}+20 \% \mathrm{CO}_{2}$ or $20 \% \mathrm{CO}_{2}$ atmosphere. In contrast, the 4-methoxyglucobrassicin content increased during storage under low $\mathrm{O}_{2}$ atmosphere and increased further after transfer to air.
\end{abstract}

Plants belonging to the order Capparales including Brassicaceae, are characterized by their content of glucosinolates (Bjerg and Sorensen, 1987a). Glucosinolates and their breakdown products are important aroma and flavor compounds in Brassica vegetables (MacLeod, 1976), such as cabbage, Brussels sprouts, broccoli, cauliflower, and horseradish. The most notable example is ally 1 isothiocyanate in mustard and horseradish arising from enzymic breakdown of sinigrin. This compound causes a pungent and lachrymatory response upon cutting and chewing (Gilbert and Nursten, 1972). Indol-3-ylmethylglucosinolates, which occur in appreciable amounts in several Brassica vegetables, are of interest for their potential contribution of anticarcinogenic compounds to the diet (Loft et al., 1992; McDanell et al., 1988).

Glucosinolates have a well defined structure with a side chain (R-group) and $D$-glucopyranose as $\beta$ - thioglucoside attached to carbon atom no. 0 in (Z)-N-hydroximine sulfate esters (Table 1) (Olsen and Sorensen, 1981; Sorensen, 1990). The structural variation of the more than 100 glucosinolates isolated from various plant sources is mainly in the R-group (Fenwick and Heaney, 1983; Sørensen, 1990). This is also the case for glucosinolates identified as constituents of Brassica vegetables (Table 1).

Total and individual glucosinolate contents vary among cultivars and plant parts (Lewis and Fenwick, 198; Olsen and Sorensen, 1981;

Received for publication 3 Jan. 1995. Accepted for publication 8 May 1995. This study was funded by grants from the Danish Agricultural and Veterinary Research Council (grant no 13-4332) and the Danish Research Academy. We thank Mann Packing Co., Salinas, Calif., for broccoli samples. The cost of publishing this paper was defrayed in part by the payment of page charges. Under postal regulations, this paper therefore must be hereby marked advertisement solely to indicate this fact.

${ }^{1}$ Dept. of Dairy and Food Science.

${ }^{2}$ Ministry of Agriculture and Fisheries, The Danish Institute of Plant and Soil Science, Dept. of Food Science and Technology, 5792 Aarslev, Denmark. To whom reprint requests should be addressed.

${ }^{3}$ Chemistry Dept.

${ }^{4}$ Dept. of Vegetable Crops, Mann Laboratory.
Sang et al., 1984; Rahman et al., 1986; VanEtten et al., 1976), but the concentration is also affected by nutrient level and cultivation practice (Heaney et al., 1983; Josefsson, 1970). During the plants growth and development, glucosinolates are synthesized from amino acids in a series of steps (Ettlinger and Kjær, 1968; Kjær, 1960; Kjær and Larsen, 1980; Underhill and Kirkland, 1980), where many details are still unknown (Bjerg et al., 1987; Sørensen, 1991).

At present, only limited information is available relating to glucosinolate metabolism in Brassica vegetables after harvest. Chong and Bérard (1983) reported the variation in glucosinolate breakdown products in three cabbage cultivars during refrigerated storage. They found that the concentration of the thiocyanate ion, volatile isothiocyanates, and goitrin declined during storage and this was associated with decreasing quality of the cabbage. Similar results were observed in cabbage stored under controlled atmosphere (CA), except that the cabbage had more volatile isothiocyanates and goitrin during the early storage period and the content declined at a higher rate towards the end of storage (Bérard and Chong, 1985). Others (Hansen, 1979; Toivonen et al., 1982) found that white cabbage stored under CA increased in pungency, mustiness, and bitterness, but they did not study changes in glucosinolate content.

Broccoli is a commodity that benefits from storage under increased $\mathrm{CO}_{2}$ and reduced $\mathrm{O}_{2}$ concentrations (Lipton and Harris, 1974; Makhlouf et al., 1989). Short term storage of broccoli under CA or in film wraps was found to extend shelf life and maintain quality by delaying yellowing and reducing loss of chlorophyll and ascorbic acid (Forney and Rij, 1991; Wang, 1979). It is not known to what extent increased $\mathrm{CO}_{2}$ and reduced $\mathrm{O}_{2}$ concentrations may affect glucosindlate content and thus flavor and nutritional quality of broccoli during storage. The objective of the present study was to determine the total and individual glucosinolates in broccoli stored under low $\mathrm{O}_{2}$ and high $\mathrm{CO}_{2}$ to understand better glucosinolate metabolism in Brassica vegetables after harvest. 
Table 1. Numbers, structures and names of glucosinolates reported as constituents of Brassica vegetables ${ }^{2}$.

\begin{tabular}{|c|c|c|c|c|}
\hline No & Structure of R-groups & $\begin{array}{l}\text { Semisystematic names } \\
\text { of R-groups } \mathrm{x}\end{array}$ & Trivial names & Brassica spp. \\
\hline 1 & $\mathrm{CH}_{2}=\mathrm{CH}-\mathrm{CH}_{2}-$ & Ally! & Sinigrin & Cabbagc, Brusscls sprouts, cauliflower, broccoli \\
\hline 2 & $\mathrm{CH}_{2}=\mathrm{CH}-\mathrm{CH}_{2}-\mathrm{CH}_{2}-$ & But-3-enyl & Gluconapin & Cabbage, Brussels sprouts, cauliflower, broccoli, Chinese cabbage \\
\hline 3 & $\mathrm{CH}_{2}=\mathrm{CH}-\mathrm{CH}_{2}-\mathrm{CH}_{2}-\mathrm{CH}_{2}-$ & Pent-4-enyl & Glucobrassicanapin & Cauliflower, broccoli, Chinese cabbage \\
\hline 4 & $\begin{array}{c}\mathrm{CH}_{2}=\mathrm{CH}-\mathrm{CH}-\mathrm{CH}_{2}- \\
1 \\
\mathrm{OH}\end{array}$ & (2R)-2-Hydroxybut-3-enyl & Progoitrin & Cabbage, Brussels sprouts, cauliflower, broccoli, Chinese cabbage \\
\hline 7 & $\mathrm{CH}_{3}-\mathrm{S}-\mathrm{CH}_{2}-\mathrm{CH}_{2}-\mathrm{CH}_{2}-$ & 3-Methylthiopropyl & Glucoibervirin & Cabbage, cauliflower, \\
\hline 8 & $\mathrm{CH}_{3}-\mathrm{S}-\mathrm{CH}_{2}-\mathrm{CH}_{2}-\mathrm{CH}_{2} \cdot \mathrm{CH}_{2}-$ & 4-Methylthiobutyl & Glucoerucin & Cabbage, Brussels sprouts, cauliflower, broccoli \\
\hline 10 & $\mathrm{CH}_{3}-\mathrm{SO}-\mathrm{CH}_{2}-\mathrm{CH}_{2}-\mathrm{CH}_{2}-$ & 3-Methylsulphinylpropyl & Glucoiberin & Cabbage, Brussels sprouts, cauliflower, broccoli \\
\hline 11 & $\mathrm{OH}_{3}-\mathrm{SO}-\mathrm{CH}_{2}-\mathrm{CH}_{2}-\mathrm{CH}_{2}-\mathrm{CH}_{2}-$ & 4-Methylsulphinylbutyl & Glucoraphanin & Cabbage, Brussels sprouts, cauliflower, broccoli, Chinese cabbage \\
\hline 12 & $\mathrm{OH}_{3}-\mathrm{SO}-\mathrm{CH}_{2}-\mathrm{CH}_{2}-\mathrm{CH}_{2}-\mathrm{CH}_{2}-\mathrm{CH}_{2}-$ & 5-Methylsulphinylpentyl & Glucoalyssin & Chinese cabbage \\
\hline 15 & $\mathrm{CH}_{3}-\mathrm{SO}_{2}-\mathrm{CH}_{2}-\mathrm{CH}_{2}-\mathrm{CH}_{2}-\mathrm{OH}_{2}-$ & 4-Methylsulphonylbutyl & Glucoerysolin & Cabbage \\
\hline 16 & & Benzyl & Glucotropaeolin & Cabbage \\
\hline 17 & & Phenethyl & Gluconasturtiin & Cabbage. Brussels sprouts. broccoli. Chinese cabbage \\
\hline 23 & $-R_{1}=H \quad R_{4}=H$ & Indol-3-ylmethyl & Glucobrassicin & Cabbage, Brussels sprouts, cauliflower, broccoli, Chinese cabbage \\
\hline 24 & $\mathrm{R}_{1}=\mathrm{OCH}_{3} \quad \mathrm{R}_{4}=\mathrm{H}$ & N-Methoxyindol-3-ylmethyl & Neoglucobrassicin & Cabbage, Brussels sprouts, cauliflower, broccoli, Chinese cabbage \\
\hline 26 & $\mathrm{R}_{1}=\mathrm{H} \quad \mathrm{R}_{4}=\mathrm{OH}$ & 4-Hydroxyindol-3-ylmethyl & 4-Hydroxygluonbrassicin & Cabbage, Brussels sprouts, cauliflower, broccoli. Chinese cabbage \\
\hline 27 & $\mathrm{R}_{1}=\mathrm{H} \quad \mathrm{R}_{4}=\mathrm{OCH}_{3}$ & 4-Methoxyindol-3-ylmethyl & 4-Methoxyglucobrassicin & Cabbage, Brussels sprouts, cauliflower, brocccoli, Chinese cabbage \\
\hline
\end{tabular}

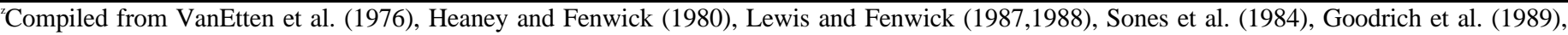
and Lewis et al. (1991).

${ }^{x}$ The semisystematic names of glucosinolates are composed of the name of the R-group followed by the word glucosinolate, e.g., allylglucosinolate for number-1 (Sorensen, 1990 and references cited therin).

\section{Materials and Methods}

Plant material. 'Marathon' Broccoli heads (Brassica oleracea L. var. italica) were obtained on the day of harvest from Mann Packing Co., Salinas, Calif., top-iced and transported to the Mann Laboratory, Davis, Calif. where they were stored overnight at $0 \mathrm{C}$. Miniflorets, $25 \mathrm{~mm}$ long and 20 to $70 \mathrm{~mm}$ in diameter, were excised from uniform heads of prime quality, surface sterilized in distilled water containing $100 \mathrm{ppm} \mathrm{NaOCl}$ for $5 \mathrm{~min}$, drained, and divided on the basis of floret diameter into small $(<40 \mathrm{~mm})$, medium (40 to $50 \mathrm{~mm})$ and large $(>50 \mathrm{~mm})$ sizes.

Storage under CA. Samples of broccoli $(650 \mathrm{~g})$ in a 1:2:1 (by weight) ratio of each floret size were placed in a 3.8-liter glass jar as one replicate, closed with a neoprene rubber stopper fitted with inlet and outlet polyethylene tubes. The jars were placed in a room at $10 \mathrm{C}$ for 7 days and ventilated with humidified gas at $10.1 \pm 0.3$ liters $\cdot \mathrm{h}^{-1}$. The atmospheres were as follows: air, $0.5 \% \mathrm{O}_{2}, 0.5 \% \mathrm{O}_{2}+20 \% \mathrm{CO}_{2}$, or $20 \% \mathrm{CO}_{2}$ (all balanced with $\mathrm{N}_{2}$ ). After 7 days, the jars were transferred to air for 2 days at $10 \mathrm{C}$. Oxygen and $\mathrm{CO}_{2}$ concentrations were verified daily by analyzing 0.5 to $3 \mathrm{ml}$ gas samples by electrochemical (model S-3All; Applied Electrochemical, Sunnyvale, Calif.) and infrared analyzers (model PIR-2000; Horiba, Irvine, Calif.). The variation in $\mathrm{O}_{2}$ and $\mathrm{CO}_{2}$ concentrations was within $\pm 5 \%$. After 2,7 , and 9 days of storage, two samples per treatment were removed for analysis except from the treatment with $20 \% \mathrm{CO}_{2}$ atmosphere. In this treatment, samples were only removed at days 7 and 9 .

Freeze-drying. Freshly harvested and stored broccoli florets (50 g) were frozen in liquid $\mathrm{N}_{2}$ and kept in polyethylene bags at $-40 \mathrm{C}$ until freeze-drying, usually within 1 month. Freeze-dried broccoli tissue was stored in sealed polyethylene bags at $4 \mathrm{C}$ until analysis.

Extraction and isolation of glucosinolates. Glucosinolates were extracted from freeze-dried, finely ground broccoli powder by the method of Bjerg et al. (1984). The samples $(0.2 \mathrm{~g})$ were spiked with a $100 \mu \mathrm{l}$ internal standard solution containing $5.0 \mu \mathrm{mol} \cdot \mathrm{ml}^{-1}$ of sinigrin and glucobarbarin, and extracted three times with $5 \mathrm{ml}$ boiling 70\% methanol for 2 min using an Ultra-Turrax Homogenizer (Ika-Labortechnik, Staufen, Germany). The extract obtained after centrifugation was concentrated to dryness in vacuo, and the residue was dissolved in $2 \mathrm{ml}$ deionized water. Desulfoglucosinolates were prepared and quantitatively determined by HPLC according to Bjerg and Sorensen (1987b) and Sorensen (1990). The glucosinolate concentration was calculated using glucobarbarin as internal standard.

Statistical analysis. Statistical significance was assessed for total and individual glucosinolates by one-way and two-way ANOVA for unbalanced data (SAS, Cary, N.C.). The sources of variation were treatment (air, $0.5 \% \mathrm{O}_{2}, 0.5 \% \mathrm{O}_{2}+20 \% \mathrm{CO}_{2}$, and $\left.20 \% \mathrm{CO}_{2}\right)$ and time $(0,2,7$, and 9 days). Duncan's multiple range test and 95\% confidence interval, respectively, were used to assess the location of the significant differences obtained. 


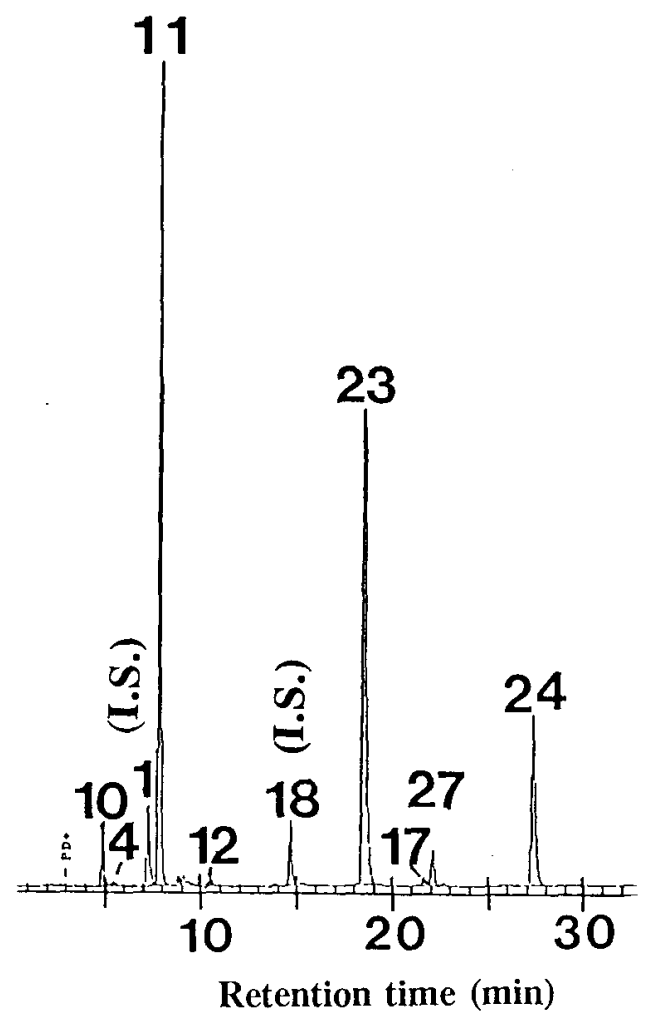

Fig. 1. Chromatogram of desulfoglucosinolates identified in freshly harvested 'Marathon' broccoli. The numbers refer to Table 1. No. 1 (sinigrin) and 18 (glucobarbarin) are internal standards (I.S.).

\section{Results and Discussion}

Total and individual glucosinolates. HPLC separation of individual desulfoglucosinolates from freshly harvested 'Marathon' broccoli is shown in Fig. 1. The broccoli contained glucoraphanin (11), glucobrassicin (23), neoglucobrassicin (24), glucoiberin (10), 4-methoxyglucobrassicin (27), progoitrin (4), glucoalyssin (12), and gluconasturtiin (17). The major glucosinolates (found in concentrations $>1 \mu \mathrm{mol} \cdot \mathrm{g}^{-1}$ dry weight) were glucoraphanin, glucobrassicin, glucoiberin, neoglucobrassicin, glucoiberin and 4methoxyglucobrassicin. Others (Goodrich et al., 1989; Lewis et

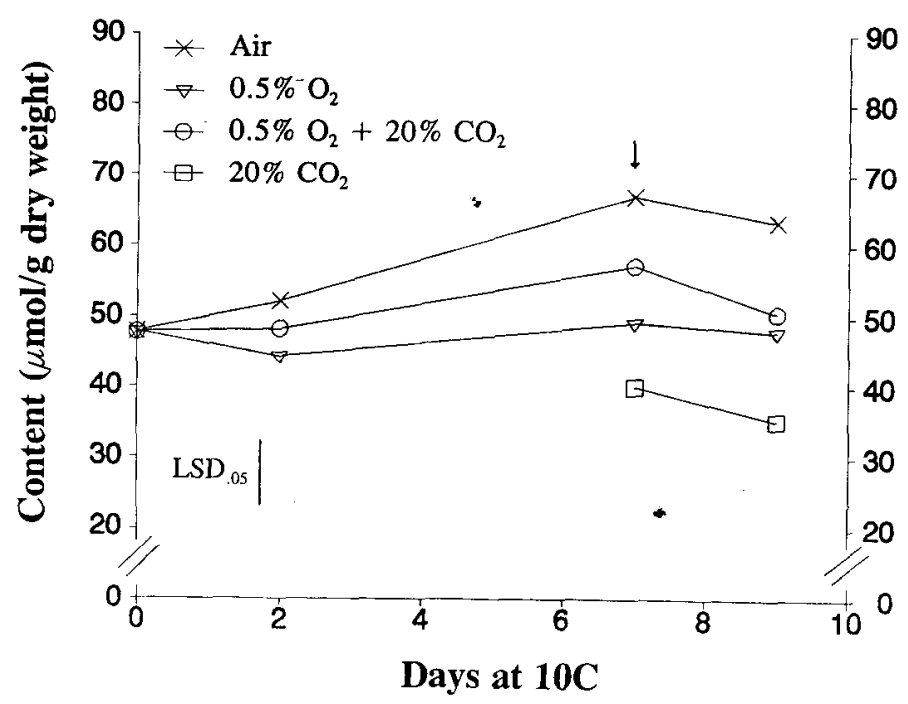

Fig. 2. Total glucosinolate content in broccoli stored 7 days under CA followed by 2 days aeration ( $\Downarrow$ transfer to air). Data are means of two replicates.

\section{Methylsulphinylalkylglucosinolates}
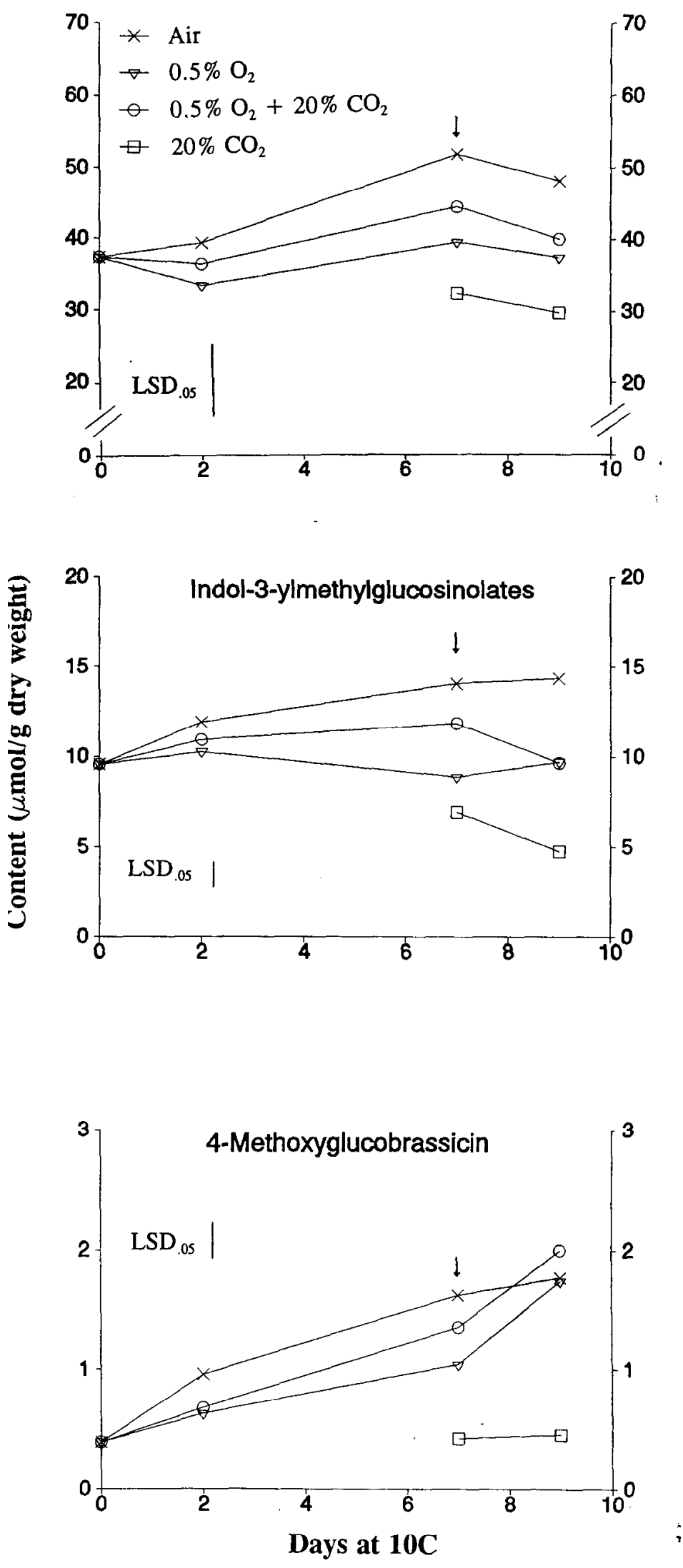

Fig. 3. Content of methylsulfinylalkylglucosinolates (glucoiberin and glucoraphanin), indol-3-ylmethylglucosinolates (glucobrassicin, neoglucobrassicin and 4methoxyglucobrassicin) and 4-methoxyglucobrassicin in broccoli stoned 7 days under CA followed by 2 days aeration ( $\Downarrow$ transfer to air). Data are means of 2 replicates. 
Table 2. Average concentration of major glucosinolates ( $\mu \mathrm{mol} \cdot \mathrm{g}^{-1} \mathrm{dry}$ weight) in 'Marathon' broccoli stored 7 days under CA and transferred to air for 2 days. The relative content of the total is indicated in parentheses.

\begin{tabular}{|c|c|c|c|c|}
\hline Glucosinolates $^{2}$ & Air & $0.5 \% \mathrm{O}_{2}$ & $0.5 \% \mathrm{O}_{2}+20 \% \mathrm{CO}_{2}$ & $20 \% \mathrm{CO}_{2}$ \\
\hline Glucoiberin & $3.2 \mathrm{a}^{\mathrm{x}}(5)$ & $2.5 \mathrm{bc}(5)$ & $2.8 \mathrm{ab}(5)$ & 2.0 c (5) \\
\hline Glucoraphanin & 46.6 a $(71)$ & 35.8 bc (73) & $39.2 \mathrm{ab}(72)$ & 29.0 c (76) \\
\hline Glucobrassicin $^{y}$ & 10.6 a (16) & 6.2 c (13) & $7.3 \mathrm{~b}(13)$ & $4.5 \mathrm{~d}(12)$ \\
\hline Neoglucobrassicin & 1.9 a (3) & 1.7 a (3) & 1.8 a (3) & $0.9 \mathrm{~b}(2)$ \\
\hline 4-Methoxyglucobrassicin & 1.7 a (3) & $1.4 \mathrm{~b}(3)$ & 1.7 a (3) & $0.4 \mathrm{c}(1)$ \\
\hline Methylsulphinylalkylglucosinolates & 49.8 c (76) & 38.3 bc (79) & $42.0 \mathrm{ab}(78)$ & 31.0 c (82) \\
\hline Indol-3-ylmethylglucosinolates & 14.2 a $(22)$ & 9.3 b (19) & $10.7 \mathrm{~b}(20)$ & 5.8 c (15) \\
\hline Total glucosinolates & 65.5 a $(100)$ & $49.0 \mathrm{~b}(100)$ & $54.2 \mathrm{~b}(100)$ & 37.9 c (100) \\
\hline
\end{tabular}

${ }^{2}$ Chemical structures are shown in Table 1.

"Numbers within a row followed by different letters are significantly different at $P=0.05$ by Duncan's multiple range test.

'Interaction between CA treatments and storage time.

"Methylsulphinylalkylglucosinolates: glucoiberin and glucoraphanin.

'Indol-3-ylmethylglucosinolates: glucobrassicin, neoglucobrassicin and 4-methoxyglucobrassicin.

al., 1991) reported a similar glucosinolate profile in broccoli. Of the major glucosinolates, the methylsulfinylalkylglucosinolates (glucoiberin and glucoraphanin) and the indol-3-ylmethylglucosinolates (glucobrassicin, neoglucobrassicin and 4-methoxyglucobrassicin) accounted for $78 \%$ and $20 \%$ of the total content, respectively, in freshly harvested broccoli.

Storage under air. Total glucosinolate content increased from $47.1 \mu \mathrm{mol} \cdot \mathrm{g}^{-1}$ dry weight at day 0 to $67.0 \mu \mathrm{mol} \cdot \mathrm{g}^{-1}$ dry weight at day 7 followed by a slight decline at day 9 as the broccoli deteriorated (Fig. 2). Incipient yellowing of florets was observed on day 7 and at day 9 the flower buds were moderate yellow (Hansen, 1993). Although the total glucosinolate content differed during air storage, none of the contents were significantly different from the others, probably due to too few observations. Chong and Bérard (1983) demonstrated that the concentration of glucosinolate products from cabbage increased during cold storage until the cabbage began to senescence, then the content rapidly declined. Analysis of variance for the content of individual glucosinolates indicated significant differences $(\mathrm{P}=0.05)$ for 4-methoxyglucobrassicin. The content increased from $0.4 \mu \mathrm{mol} \cdot \mathrm{g}^{-1}$ dry weight at day 0 to 1.8 $\mu \mathrm{mol} \cdot \mathrm{g}^{-1}$ dry weight at day 9 in air stored broccoli.

Storage under $C A$. The green color of the florets was maintained under the three CA conditions used. The $20 \% \mathrm{CO}_{2}$ atmosphere resulted in severe off-odors. The total glucosinolate content increased $42 \%$ and $21 \%$ during 7 days storage under air and $0.5 \% \mathrm{O}_{2}+20 \% \mathrm{CO}_{2}$, respectively, as compared to freshly harvested broccoli (Fig. 2). This increase could have been associated with enhanced synthesis or a release of bound compounds during storage. Total glucosinolate 'content did not change for broccoli stored under $0.5 \% \mathrm{O}_{2}$, but decreased $15 \%$ in broccoli stored under
$20 \% \mathrm{CO}_{2}$ in the absence of $\mathrm{O}_{2}$. Exudation of cell sap, a symptom of physiological injury of the tissue, was visible in these latter samples. This symptom probably reflected membrane damage and cell rupture, conditions favorable for hydrolytic breakdown of glucosinolates by myrosinase catalyzed hydrolysis or autolysis (Olsen and Sorensen, 1981; Sorensen, 1990). In the intact cell, myrosinases are well separated from glucosinolates (Lüthy and Matile, 1984). When glucosinolates and myrosinases are brought in contact, a number of volatile and nonvolatile degradation products are formed depending on the structures of the glucosinolates and myrosinases and the actual conditions for hydrolysis (Sorensen, 1990; VanEtten and Tookey, 1983). During air and CA storage, the variation in the methylsulphinylalkylglucosinolate content (Fig. 3) was similar in both trend and magnitude to that of the total glucosinolates (Fig. 2). This result was in part due to the high relative content of methylsulphinylalkylglucosinolates $(76 \%$ to $82 \%)$ in all samples (Table 2). The indol3 -ylmethylglucosinolate content $(15 \%$ to $22 \%$ of total) increased $47 \%$ and $24 \%$ during 7 days storage under air and $0.5 \% \mathrm{O}_{2}+20 \%$ $\mathrm{C} \mathrm{O}_{2}$ atmosphere, respectively, as compared to freshly harvested broccoli (Fig. 3). In contrast, the concentration did not change under $0.5 \% \mathrm{O}_{2}$ and decreased $28 \%$ following 7 days storage under $20 \% \mathrm{CO}_{2}$ (Fig. 3). No significant differences were found between the relative content of methylsulfinylalkyl- and indol-3ylmethylglucosinolates with regard to $\mathrm{CA}$ treatment and storage period.

The average concentrations of total and individual glucosinolates for day 7 to 9 are shown in Table 2. Broccoli stored under air had the highest content of glucosinolates followed by that stored under $0.5 \% \mathrm{O}_{2}+20 \% \mathrm{CO}_{2}, 0.5 \% \mathrm{O}_{2}$, and $20 \% \mathrm{CO}_{2}$ (Table 2). There were

Table 3. Significance of CA treatments, storage time ${ }^{z}$, and interactions for content of total and individual glucosinolates, methylsulphinylalkylglucosinolates and, indol-3-yhnethylglucosinolates .

\begin{tabular}{|c|c|c|c|c|c|c|c|c|}
\hline & $\begin{array}{l}\text { Gluco- } \\
\text { iberin }\end{array}$ & $\begin{array}{c}\text { Gluco- } \\
\text { raphanin }\end{array}$ & $\begin{array}{c}\text { Gluco- } \\
\text { brassicin }\end{array}$ & $\begin{array}{c}\text { Neo- } \\
\text { glucobrassicin }\end{array}$ & $\begin{array}{l}\text { 4-Methoxy- } \\
\text { glucobrassicin }\end{array}$ & $\begin{array}{l}\text { Methylsulphinyl- } \\
\text { alkyl- } \\
\text { glucosinolates }\end{array}$ & $\begin{array}{l}\text { Indol-3-yl- } \\
\text { methyl- } \\
\text { glucosinolates }\end{array}$ & $\begin{array}{c}\text { Total } \\
\text { glucosinolates }\end{array}$ \\
\hline CA-treatment & $* *$ & $* *$ & $* * *$ & $* *$ & $* * *$ & $*$ & $* * *$ & $* * *$ \\
\hline Storage time & NS & NS & $* *$ & NS & $* *$ & NS & NS & NS \\
\hline Interaction & NS & NS & $*$ & NS & $*$ & NS & NS & NS \\
\hline
\end{tabular}

Day 7 and 9.

${ }^{x}$ Methylsulphinylalkylglucosinolates: glucoiberin and glucoraphanin.

'Indol-3-ylmethylglucosinolates: glucobrassicin, neoglucobrassicin and 4-methoxyglucobrassicin.

Ns*,*****Nonsignificant or significant at $P=0.01,0.001$ and 0.0001 , respectively. 
significant differences among CA-treatments in the content of total and individual glucosinolates for day 7 to 9 (Table 3).

When the broccoli stored under CA for 7 days was transferred to air for 2 days, there was not a significant decrease in total glucosinolate content (Table 3). Storage period (transfer to air from day 7 to 9) only affected glucobrassicin and 4methoxyglucobrassicin contents. Aeration reduced the glucobrassicin contents $35 \%$ in broccoli stored 7 days under either $0.5 \% \mathrm{O}_{2}+20 \% \mathrm{CO}_{2}$ or $20 \% \mathrm{CO}_{2}$. Treatment with $0.5 \% \mathrm{O}_{2}+20 \%$ $\mathrm{CO}_{2}$ probably caused physiological stress in the tissue even though no symptoms of $\mathrm{CO}_{2}$ injury were visible. This could result in an increase in the hydrolytic breakdown of glucosinolates upon aeration. On average, the glucobrassicin content decreased from $7.8 \mu \mathrm{mol} \cdot \mathrm{g}^{-1}$ dry weight at day 7 to $6.5 \mu \mathrm{mol} \cdot \mathrm{g}^{-1}$ dry weight at day 9. The opposite result was noted for 4-methoxyglucobrassicin (Fig. 3). The content increased during storage under low 0 , atmosphere and increased further after transfer to air. The average content of 4-methoxyglucobrassicin increased from $1.1 \mu \mathrm{mol} \cdot \mathrm{g}^{-1}$ dry weight at day 7 to $1.5 \mu \mathrm{mol} \cdot \mathrm{g}^{-1}$ dry weight at day 9 . These results may indicate that storage could affect the nutritional value of broccoli since degradation products of indol-3-ylmethylglucosinolates, especially substituted indol-3-ylmethylglucosinolates, have been shown to have anticarcinogenic effects (Feldt et al., 1994 and references cited therein; Loft et al., 1992). In the present study, very low $\mathrm{O}_{2}$ and very high $\mathrm{CO}_{2}$ were imposed. Glucosinolate metabolism of broccoli stored at lower temperature and very extreme CA conditions should be investigated.

\section{Literature Cited}

Berard, L.S. and C. Chong. 1985. Influence of storage on glucosinolate fluctuations in cabbage. Acta Hort. 157:203-210.

Bjerg, B. and H. Sorensen. 1987a. Isolation of intact glucosinolates by column chromatography and determination of their purity, 59-75. In: J.P. Wathelet (ed.). World crops: Production, utilization, description. Glucosinolates in rapeseeds: Analytical aspects. Martinus Nijhoff Publ., Boston.

Bjerg, B. and H. Sorensen. 1987b. Quantitative analysis of glucosinolates in oilseed rape based on HPLC of desulfoglucosinolates and HPLC of intact glucosinolates, p. 125-150. In: J.P. Wathelet (ed.). World crops: Production, utilization, description. Glucosinolates in rapeseeds: Analytical aspects. Martinus Nijhoff Publ., Boston.

Bjerg, B., O. Olsen, K.W. Rasmussen, and H. Sorensen. 1984. New principles of ion-exchange techniques suitable to sample preparation and group separation of natural products prior to liquid chromatography. J. Liquid Chromatography 7:691-707.

Bjerg, B., P.W. Kachlicki, L.M. Larsen, and H. Sorensen. 1987. Metabolism of glucosinolates. Proc. 7th Intl. Rapeseed Congress, Poznan, Poland. 2:496-506.

Chong, C. and L.S. Bérard. 1983. Changes in glucosinolates during refrigerated storage of cabbage. J. Amer. Soc. Hort. Sci. 108:688-691.

Ettlinger, M.G. and A. Kjaer. 1968. Sulfur compounds in plants, p. 58144. In: T.J. Mabry, R.E. Alston, and V.C. Runeckels (eds.). Recent advances in phytochemistry. Appleton-Century-Crofts, New York.

Fenwick, G.R. and R.K. Heaney. 1983. Glucosinolates and their breakdown products in cruciferous crops, foods and feeding stuffs. Food Chem. 11:249-271.

Feldt, C., P. Moller, J. Otte, and H. Sorensen. 1994. Micellar electrokinetic capillary chromatography for determination of indolyl glucosinolates and transformation products thereof. Ann. Biochem. 217:62-69.

Forney, C.F. and R.E. Rij. 1991. Temperature of broccoli florets at time of packaging influences package atmosphere and quality. HortScience 26:1301-1303.

Gilbert, J. and H.E. Nursten. 1972. Volatile constituents of horseradish roots. J. Sci. Food Agr. 23:527-539.

Goodrich, R.M., J.L. Anderson, and G.S. Stoewsand. 1989. Glucosinolate changes in blanched broccoli and Brussels sprouts. J. Food Processing and Preserving 13:275-280.

Hansen, H. 1979. Organoleptic evaluation of white cabbage stored in commercial storage rooms at different level of $\mathrm{CO}_{2}$. Acta Hort. 93:29-44.

Hansen, M. 1993. Volatile and non-volatile constituents and sensory quality of broccoli stored under low $\mathrm{O}_{2}$ and high $\mathrm{CO}_{2}$ atmosphere. $\mathrm{PhD}$ diss. The Royal Veterinary and Agr. Univ., Copenhagen.

Heaney, R.K. and G.R. Fenwick. 1980. Glucosinolates in Brassica vegetables. Analysis of 22 varieties of Brussels sprout (Brassica oleracea var. gemmifera). J. Sci. Food Agr. 31:785-793.

Heaney, R.K., E.A. Spinks, and G.R. Fenwick. 1983. The glucosinolate content of Brussels sprouts: Factors affecting their relative abundance. Z. Pflanzenzüchtg. 91:219-226.

Josefsson, E. 1970. Glucosinolate content and amino acid composition of rapeseed (Brassica napus) meal as affected by sulphur and nitrogen nutrition. J. Sci. Food Agr. 21:98-103.

Kjær, A. 1960. Naturally derived isothiocyanates (mustard oil) and their parent glucosides, p. 122-176. In: W. Hetz, H. Grisebach, and G.W. Kirby (eds.). Progress in the chemistry of organic natural products. Springer-Verlag, New York.

Kjær, A. and P.O. Larsen. 1980. Non-protein amino acids, cyanogenic glucosides, and glucosinolates. Biosynthesis, specialist periodical report. Chem. Soc. London 6; 5(1977): 120-135; 4(1976):179-203; 2(1973):71-105.

Lewis, J. and G.R. Fenwick. 1987. Glucosinolate content of Brassica vegetables: analysis of twenty-four cultivars of calabrese (green sprouting broccoli, Brassica oleracea L. var. botrytis subvar. cymosa Lam.). Food Chem. 25:259-268.

Lewis, J. and G.R. Fenwick. 1988. Glucosinolate content of Brassica vegetables-Chinese cabbage pe-tsai (Brassica pekinensis) and pakchoi (Brassica chinensis). J. Sci. Food Agr. 45:379-386.

Lewis, J.A., G.R. Fenwick, and A.R. Gray. 1991. Glucosinolates in Brassica vegetables: green-curded cauliflowers (Brassica oleracea L. Botrytis group) and purple-headed broccoli (B. oleracea L. Italica group). Lebensm.-Wiss. u.-Technol. 24:361-363.

Lipton, W.J. and C.M. Harris. 1974. Controlled atmosphere effects on the market quality of stored broccoli (Brassica oleracea L., Italica Group). J. Amer. Soc. Hort. Sci. 99:200-205.

Loft, S., J. Otte, H.E. Poulsen, and H. Sorensen. 1992. Influence of intact and myrosinase-treated indolyl glucosinolates on the metabolism in vivo of metronidazole and antipyrine in the rat. Food Chem. Toxicity 30:927-935.

Lüthy, B. and P. Matile. 1984. The mustard oil bomb: rectified analysis of the subcellular organisation of the myrosinase system. Biochem. Physiol. Pflanzen 179:5-12.

MacLeod, A.J. 1976. Volatile flavour compounds of the cruciferae, p. 307-330. In: J.G. Vanghan, A.J. MacLeod, and B.M.G. Jones (eds.). The biology and chemistry of the cruciferae. Academic Press, New York.

Makhlouf, J., F. Castaigne, J. Arul, C. Willemot, and A. Gosselin. 1989. Long-term storage of broccoli under controlled atmosphere. HortScience 24:637-639.

McDanell, R., A.E.M. McLean, A.B. Hanley, R.K. Heaney, and G.R. Fenwick. 1988. Chemical and biological properties of indole glucosinolates (glucobrassicins): A review. Food Chem. Toxicity 26:59-70.

Olsen, O. and H. Sorensen. 1981. Recent advances in the analysis of glucosinolates. J. Amer. Oil Chem Soc. 58:857-865.

Rahman, M.H., O. Stolen, and H. Sørensen. 1986. Glucosinolate content in seed from silique at different position of Brassica campestris. Acta Agr. Scandinavia 36:318-324.

Sang, J.P., I.R. Minchinton, P.K. Johnstone, and R.J.W. Truscott. 1984. Glucosinolate profiles in the seed, root and leaf tissue of cabbage, mustard, rapeseed, radish, andswede. Can. J. Plant Sci. 64:77-93.

Sones, K., R.K. Heaney, and G.R. Fenwick. 1984. Glucosinolates in Brassica vegetables. Analysis of twenty-seven cauliflower cultivars (Brassica olerucea L. var. botrytis subvar. cauliflora DC). J. Sci. Food Agr. 35:762-766.

Sorensen, H. 1990. Glucosinolates: Structure-Properties-Function, p. 149-172. In: F. Shahidi (ed.). Rapeseed/canola: Production, chemistry, 
nutrition and processing technology. Van Nostrand Reinhold Publ., New York.

Sorensen, H. 1991. Chemistry, VI:1931-1934. In: GCIRC-Congress, repporteur evaluation. Summary of presentations in this section and review of recent years progress. GCIRC-Congr., Saskatoon, Can.

Toivonen, P., J. Walsh, E.C. Lougheed, and D.P. Murr. 1982. Ethylene relationships in storage of some vegetables. In: D.G. Richardson and M. Meherivk (eds.). Controlled atmospheres for storage and transport of perishable agricultural commodities. Oregon State Univ., Symp. Ser. 1. Timber Press, Ore.

Underhill, E.W. and D.F. Kirkland. 1980. Glucosinolates, p. 493-5 11. In:
E.A. Bell and B.V. Charlwood (eds.). Secondary plant products: Encyclopedia of plant physiology. Springer-Verlag, New York.

VanEtten, C.H. and H.L. Tookey. 1983. Glucosinolates, p. 15-30. In: M. Rechcigl (ed.). CRC handbook of naturally occurring food toxicants. CRC Press, Boca Raton, Fla.

VanEtten, C.H., M.E. Daxenbichler, P.H. Williams, and W.F. Kwolek. 1976. Glucosinolates and derived products in cruciferous vegetables. Analysis of the edible part from twenty-two varieties of cabbage. J. Agr. Food Chem. 25:259-268.

Wang, C.Y. 1979. Effect of short-term high CO, treatment on the marketing quality of stored broccoli. J. Food Sci. 44:1478-1482. 